\title{
Analisis Algoritma Datamining pada Kasus Daerah Pelaku Kejahatan Pencurian Berdasarkan Provinsi
}

\author{
Rinawati $^{1}$, Erene Gernaria Sihombing ${ }^{2}$, Linda Sari Dewi ${ }^{3}$, Ester Arisawati ${ }^{4}$ \\ 1,2,3,4 STMIK Nusa Mandiri, Jakarta, Indonesia \\ rinawati.riw@nusamandiri.ac.id
}

\begin{abstract}
Theft is a behavior that causes harm to victims who are targeted and can cause victims. The level of theft behavior is increasing in each region due to the increasing number of unemployment and lazy nature of work that makes a person commit theft to make ends meet. The purpose of this study was to analyze using the technique of datamining in the area of perpetrators of theft crimes by province. The technique used is clustering with the K-means method. Data sourced from the Indonesian Central Statistics Agency with the url address: https://www.bps.go.id/. The results of the study using this technique are clustered in areas in Indonesia which have the highest crime theft rates. From the results of the study using the $K$ means technique, that there are 17 provinces out of 34 provinces that have the highest crime theft (C1) areas, namely: Aceh, North Sumatra, West Sumatra, Riau, Jambi, South Sumatra, Lampung, DKI Jakarta, West Java, Central Java, East Java, Banten, West Nusa Tenggara, East Nusa Tenggara, South Kalimantan, South Sulawesi, Papua. The results of the study are expected to be information for the government in conducting policies to reduce the crime crime rate in Indonesia which is very high (50\%).
\end{abstract}

Keywords: Datamining, Klastering, K-means, Theft Crime, Indonesia

\begin{abstract}
Abstrak
Pencurian merupakan perilaku yang menyebabkan kerugian bagi korban yang menjadi sasaran dan bisa menyebabkan korban. Tingkat perilaku pencurian semakin meningkat di setiap daerah karena semakin banyaknya tingkat pengangguran dan sifat malas bekerja yang membuat seseorang melakukan pencurian untuk memenuhi kebutuhan hidupnya. Tujuan penelitian adalah untuk menganalisa dengan menggunakan teknik datamining pada daerah pelaku kejahatan pencurian berdasarkan provinsi. Teknik yang digunakan adalah klastering dengan metode K-means. Data bersumber dari Badan Pusat Statistik Indonesia dengan alamat url: https://www.bps.go.id/. Hasil dari penelitian dengan menggunakan teknik ini adalah berupa cluster terdapat daerah di Indonesia yang memiliki tingkat kejahatan pencurian tertinggi. Dari hasil penelitian menggunakan teknik K-means, bahwa terdapat 17 provinsi dari 34 provinsi yang daerah pelaku kejahatan pencurian tertinggi (C1) yakni: Aceh, Sumatera Utara, Sumatera Barat, Riau, Jambi, Sumatera Selatan, Lampung, DKI Jakarta, Jawa Barat, Jawa Tengah, Jawa Timur, Banten, Nusa Tenggara Barat, Nusa Tenggara Timur, Kalimantan Selatan, Sulawesi Selatan, Papua. Hasil penelitian diharapkan menjadi informasi bagi pemerintah dalam melakukan kebijakan mengurangi tingkat kejahatan pencurian di Indonesia yang sangat tinggi (> 50\%).
\end{abstract}

Kata Kunci : Datamining, Klastering, K-means, Kejahatan Pencurian, Indonesia

\section{PENDAHULUAN}

Pencurian merupakan perilaku yang melanggar hukum yang dapat menyebabkan korban jiwa, pencurian sering terjadi di pusat kota atau pusat perbelanjaan seperti pasar karena pusat keramaian memicu pelaku untuk melakukan tindakan pencurian, pelaku beroperasi secara individu atau 
berkelompok. Zaman yang semakin maju ini pengangguran semakin meningkat sehingga membuat sebagian yang tidak bekerja melakukan hal tersebut untuk memenuhi keinginan dan kebutuhannya mereka tertekan ekonomi dan sifat malas bekerja sehingga melakukan tindakan yang melanggar hukum tersebut, pelaku pencurian biasa beroperasi di pusat keramaian dan menjadikan pusat keramaian sebagai kesempatan. pelaku kejahatan biasanya beroperasi sendirian atau berkelompok dengan tugas nya masing-masing untuk memudahkan proses operasi mereka. Di setiap daerah sering terjadi tindakan pencurian bahkan setiap tahunnya tingkat kejahatan pencurian semakin meningkat karena semakin maraknya pelaku pencurian. Banyak faktor yang menyebabkan terjadinya tindakan pencurian diantaranya tingkat pengangguran yang semakin meningkat, krisis ekonomi, lingkungan dan pergaulan yang kurang baik, usia tidak menjadi halangan bagi pelaku untuk melakukan tindakan kejahatan karena faktor didikan yang kurang baik usia anak-anak, remaja, dewasa atau usia tua dapat melakukan tindak kejahatan yang merugikan tersebut.

Dari banyaknya provinsi yang tingkat kasus pencuriannya bervariasi dilakukanlah pengolahan data-data dengan metode data mining, data mining merupakan suatu metode yang digunakan untuk pengolahan data guna menemukan gambaran yang tersembunyi dari data yang diolah. Data yang diolah dengan metode data mining ini kemudian menghasilkan suatu pengetahuan baru yang berasal dari data yang lama, hasil dari pengolahan data tersebut dan digunakan dalam menentukan keputusan di masa depan. Dari kasus tersebut peneliti menerapkan algoritma $k$-means untuk mengelompokan data kasus pencurian di setiap provinsi agar proses lebih cepat dan lebih efisien, algoritma $k$-means menetapkan nilai-nilai klaster $(\mathrm{K})$ secara random, untuk sementara nilai tersebut menjadi pusat dari klaster atau disebut dengan centroid, kemudian menghitung jarak setiap data yang ada terhadap masing-masing centroid menggunakan rumus Euclidian hingga di temukan jarak yang paling dekat dari setiap data dengan centroid [1].

Adapun penelitian terdahulu yang menggunakan data mining dengan algoritma $k$-means seperti [2] dalam penerapan datamining pada populasi daging ayam ras pedaging di indonesia berdasarkan provinsi menggunakan $k$-means clustering, dimana data diolah dengan melakukan clustering dalam 3 cluster yaitu cluster tingkat populasi tinggi, cluster tingkat populasi sedang dan rendah. Windha juga menerapkan metode $k$-means untuk menentukan status gizi balita [3]. Dan [4] menerapkan metode $k$-means dalam pengelompokkan penjualan produk pada swalayan fadhila. Dimana data yang diambil di Swalayan Fadhilla Bengkulu menghasilkan dua jenis kelompok data yaitu data penjualan rendah dan data penjualan tinggi. Berdasarkan permasalahan tersebut peneliti mengangkat topik clustering pada daerah pelaku kejahatan pencurian berdasarkan provinsi dengan metode $K$-means. Diharapkan hasil penelitian ini dapat memberikan masukan kepada pemerintah dalam mengambil kebijakan tentang kejahatan pencurian berdasarkan provinsi yang selalu meresahkan masyarakat. 


\section{METODOLOGI PENELITIAN}

\subsection{Datamining}

Data mining merupakan kegiatan pengumpulan untuk menemukan keteraturan dalam set data yang besar yang digunakan untuk pengolahan data guna menemukan pola yang tersembunyi dari data yang diolah [5].

\subsection{Clustering}

Merupakan proses membagi data dalam suatu himpunan ke dalam beberapa kelompok yang kesamaan datanya dan dapat dipakai lebih lanjut dalam berbagai aplikasi secara luas seperti klasifikasi, pengolahan gambar, dan pengenalan pola [6].

\subsection{K-Means}

K-means merupakan metode non-hirarki yang berusaha mempartisi data yang ada ke dalam bentuk satu atau lebih kelompok [7]. Berikut ini flowchart metode K-means pada Gambar 1:

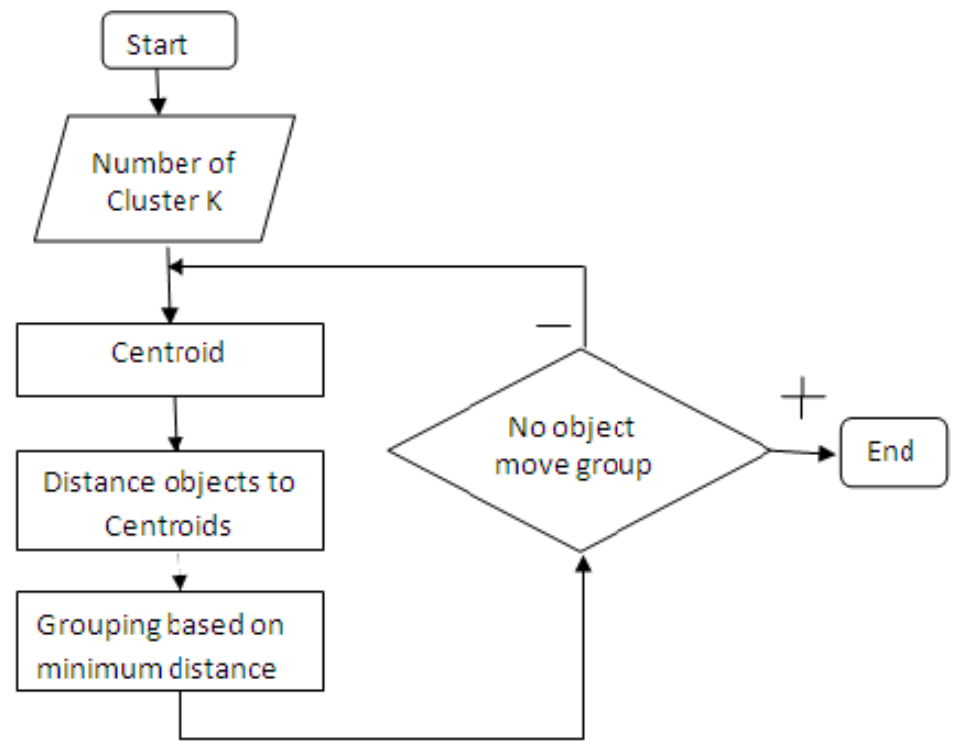

Gambar 1. Flowchat metode K-Means

Berdasarkan gambar 1 dapat dijelaskan bahwa:

a) Tentukan jumlah cluster yang ingin dibentuk dan tetapkan pusat cluster $k$.

b) Menggunakan jarak euclidean kemudian hitung setiap data ke pusat cluster.

$$
d_{i k}=\sqrt{\sum_{j}^{m}\left(C_{i j}-C_{k j}\right)^{2}}
$$

c) Kelompokkan data ke dalam cluster dengan jarak yang paling pendek dengan persamaan 


$$
\operatorname{Min} \sum_{k}^{k}=d_{i k}=\sqrt{\sum_{j}^{m}\left(C_{i j}-C_{k j}\right)^{2}}
$$

d) Hitung pusat cluster yang baru menggunakan persamaan

$$
C_{k j}=\frac{\sum_{i=1}^{p} x_{i j}}{p}
$$

Dengan xij € cluster ke - $\mathrm{k}$ dan $p=$ banyaknya anggota cluster $\mathrm{ke}-\mathrm{k}$

e) Ulangi langkah dua sampai dengan empat sehingga sudah tidak ada lagi data yang berpindah ke kluster yang lain.

\section{HASIL DAN PEMBAHASAN}

Data diperoleh dari badan pusat statistik (https://www.bps.go.id/) untuk kategori kriminal yang kemudian di kelola dari data disetiap provinsi. Data yang digunakan merupakan data tahun 2016, 2017, dan 2018 yang terdiri dari 34 provinsi.

Tabel 1. Daerah Pelaku Kejahatan Pencurian Berdasarkan Provinsi

\begin{tabular}{|l|l|l|l|l|}
\hline \multirow{2}{*}{ No } & \multicolumn{2}{|c|}{ Provinsi } & \multicolumn{3}{|c|}{ Tahun } \\
\cline { 3 - 5 } & & $\mathbf{2 0 1 6}$ & \multicolumn{1}{|c|}{$\mathbf{2 0 1 7}$} & \multicolumn{1}{|c|}{$\mathbf{2 0 1 8}$} \\
\hline 1 & Aceh & 140 & 63 & 47 \\
\hline 2 & Sumatera Utara & 186 & 93 & 141 \\
\hline 3 & Sumatera Barat & 57 & 55 & 71 \\
\hline 4 & Riau & 149 & 79 & 101 \\
\hline 5 & Jambi & 66 & 57 & 76 \\
\hline 6 & Sumatera Selatan & 279 & 221 & 430 \\
\hline 7 & Bengkulu & 38 & 33 & 40 \\
\hline 8 & Lampung & 200 & 186 & 255 \\
\hline 9 & Kep. Bangka Belitung & 24 & 16 & 15 \\
\hline 10 & Kep. Riau & 21 & 13 & 17 \\
\hline 11 & DKI Jakarta & 28 & 35 & 73 \\
\hline 12 & Jawa Barat & 297 & 287 & 344 \\
\hline 13 & Jawa Tengah & 132 & 146 & 176 \\
\hline 14 & Di Yogyakarta & 7 & 28 & 20 \\
\hline 15 & Jawa Timur & 269 & 290 & 419 \\
\hline 16 & Banten & 78 & 54 & 49 \\
\hline 17 & Bali & 8 & 13 & 23 \\
\hline 18 & Nusa Tenggara Barat & 96 & 107 & 146 \\
\hline 19 & Nusa Tenggara Timur & 61 & 54 & 67 \\
\hline 20 & Kalimantan Barat & 39 & 33 & 37 \\
\hline 21 & Kalimantan Tengah & 54 & 41 & 27 \\
\hline 22 & Kalimantan Selatan & 117 & 85 & 73 \\
\hline 23 & Kalimantan Timur & 55 & 25 & 37 \\
\hline 24 & Kalimantan Utara & 0 & 0 & 9 \\
\hline 25 & Sulawesi Utara & 22 & 27 & 21 \\
\hline 26 & Sulawesi Tengah & 21 & 24 & 23 \\
\hline 27 & Sulawesi Selatan & 69 & 54 & 47 \\
\hline 28 & Sulawesi Tenggara & 6 & 23 & 16 \\
\hline 29 & Gorontalo & 3 & 4 & 3 \\
\hline 30 & Sulawesi Barat & 23 & 7 & 7 \\
\hline & & & & \\
\hline
\end{tabular}


Jurnal Sains Komputer \& Informatika (J-SAKTI)

Volume 4 Nomor 1 Maret 2020, pp. 77-87

ISSN: 2548-9771/EISSN: 2549-7200

http://tunasbangsa.ac.id/ejurnal/index.php/jsakti

\begin{tabular}{|l|l|l|l|l|}
\hline \multirow{2}{*}{ No } & \multicolumn{1}{|c|}{ Provinsi } & \multicolumn{3}{|c|}{ Tahun } \\
\cline { 3 - 5 } & & $\mathbf{2 0 1 6}$ & $\mathbf{2 0 1 7}$ & \multicolumn{1}{|c|}{2018} \\
\hline 31 & Maluku & 0 & 9 & 20 \\
\hline 32 & Maluku Utara & 5 & 2 & 7 \\
\hline 33 & Papua Barat & 3 & 13 & 13 \\
\hline 34 & Papua & 64 & 153 & 113 \\
\hline
\end{tabular}

Sumber: Badan Pusat Statistik

Pada penjelasan tabel 1 , data akan diolah dengan mengambil nilai rata rata dari 3 tahun terakhir pada daerah pelaku kejahatan pencurian berdasarkan provinsi, sehingga diperoleh hasil seperti tabel berikut:

Tabel 2. Data yang akah digunakan

\begin{tabular}{|c|c|c|}
\hline No & Provinsi & Nilai Rata - Rata \\
\hline 1 & Aceh & 83.33333333 \\
\hline 2 & Sumatera Utara & 140 \\
\hline 3 & Sumatera Barat & 61 \\
\hline 4 & Riau & 109.6666667 \\
\hline 5 & Jambi & 66.33333333 \\
\hline 6 & Sumatera Selatan & 310 \\
\hline 7 & Bengkulu & 37 \\
\hline 8 & Lampung & 213.6666667 \\
\hline 9 & Kep. Bangka Belitung & 18.33333333 \\
\hline 10 & Kep. Riau & 17 \\
\hline 11 & DKI Jakarta & 45.33333333 \\
\hline 12 & Jawa Barat & 309.3333333 \\
\hline 13 & Jawa Tengah & 151.3333333 \\
\hline 14 & Di Yogyakarta & 18.33333333 \\
\hline 15 & Jawa Timur & 326 \\
\hline 16 & Banten & 60.33333333 \\
\hline 17 & Bali & 14.666666667 \\
\hline 18 & Nusa Tenggara Barat & 116.3333333 \\
\hline 19 & Nusa Tenggara Timur & 60.666666667 \\
\hline 20 & Kalimantan Barat & 36.33333333 \\
\hline 21 & Kalimantan Tengah & 40.666666667 \\
\hline 22 & Kalimantan Selatan & 91.666666667 \\
\hline 23 & Kalimantan Timur & 39 \\
\hline 24 & Kalimantan Utara & 9 \\
\hline 25 & Sulawesi Utara & 23.33333333 \\
\hline 26 & Sulawesi Tengah & 22.666666667 \\
\hline 27 & Sulawesi Selatan & 56.666666667 \\
\hline 28 & Sulawesi Tenggara & 15 \\
\hline 29 & Gorontalo & 3.333333333 \\
\hline 30 & Sulawesi Barat & 12.33333333 \\
\hline 31 & Maluku & 14.5 \\
\hline 32 & Maluku Utara & 4.6666666667 \\
\hline 33 & Papua Barat & 9.6666666667 \\
\hline 34 & Papua & 110 \\
\hline
\end{tabular}


Penentuan titik cluster dilakukan dengan mengambil nilai terbesar (maksimum) untuk cluster daerah pelaku kejahatan pencurian yang tingkat tinggi (C1), nilai rata-rata (average) untuk cluster daerah pelaku kejahatan pencurian tingkat sedang (C2) dan nilai terkecil (minimum) untuk cluster daerah pelaku kejahatan pencurian tingkat rendah (C3). Nilai titik tersebut seperti yang ditunjukkan pada tabel berikut:

Tabel 3. Centroid awal

\begin{tabular}{|c|c|c|}
\hline $\begin{array}{c}\text { cluster } \\
\text { tinggi }\end{array}$ & $\begin{array}{c}\text { cluster } \\
\text { sedang }\end{array}$ & $\begin{array}{c}\text { cluster } \\
\text { rendah }\end{array}$ \\
\hline 289.75 & 85.2381 & 18.44792 \\
\hline
\end{tabular}

Proses cluster dengan mengambil jarak terdekat dari setiap data yang diolah. Dari data daerah pelaku kejahatan pencurian pada tahun 2016, 2017, 2018 yang diambil nilai rata ratanya sepeti yang ditunjukkan pada tabel 2 , didapatkan pengelompokan pada iterasi 1 untuk 3 cluster tersebut. Cluster (C1) yakni 17 Provinsi : Aceh, Sumatera Utara, Sumatera Barat, Riau, Jambi, Sumatera Selatan, Lampung, DKI Jakarta, Jawa Barat, Jawa Tengah, Jawa Timur, Banten, Nusa Tenggara Barat, Nusa Tenggara Timur, Kalimantan Selatan, Sulawesi Selatan, Papua. cluster (C2) yakni 2 provinsi : Gorontalo, Maluku Utara dan cluster (C3) yakni 15 Provinsi : Bengkulu, Kep. Bangka Belitung, Kep. Riau, DI Yogyakarta, Bali, Kalimantan Barat, Kalimantan Tengah, Kalimantan Timur, Kalimantan Utara, Sulawesi Utara, Sulawesi Tengah, Sulawesi Tenggara, Sulawesi Barat, Maluku, Papua Barat. Proses pencarian jarak terpendek, pengelompokan data pada iterasi 1 dan Clustering data dapat digambarkan pada tabel dan gambar berikut:

Tabel 4. Perhitungan Jarak Pusat Cluster Iterasi 1

\begin{tabular}{|c|c|c|c|c|c|c|}
\hline No & Nama & Nilai & C1 & $\mathrm{C} 2$ & C3 & $\begin{array}{l}\text { Jarak } \\
\text { terpendek }\end{array}$ \\
\hline 1 & Aceh & 83.33 & 242.67 & 5.465686272 & 80 & 5.465686272 \\
\hline 2 & Sumatera Utara & 140 & 186 & 62.13235294 & 136.6666667 & 62.13235294 \\
\hline 3 & Sumatera Barat & 61 & 265 & 16.86764706 & 57.66666667 & 16.86764706 \\
\hline 4 & Riau & 109.67 & 216.33 & 31.79901964 & 106.3333334 & 31.79901964 \\
\hline 5 & Jambi & 66.33 & 259.67 & 11.53431373 & 63 & 11.53431373 \\
\hline 6 & Sumatera Selatan & 310 & 16 & 232.1323529 & 306.6666667 & 16 \\
\hline 7 & Bengkulu & 37 & 289 & 40.86764706 & 33.66666667 & 33.66666667 \\
\hline 8 & Lampung & 213.67 & 112.33 & 135.7990196 & 210.3333334 & 112.3333333 \\
\hline 9 & $\begin{array}{l}\text { Kep. Bangka } \\
\text { Belitung }\end{array}$ & 18.33 & 307.67 & 59.53431373 & 15 & 15 \\
\hline 10 & Kep. Riau & 17 & 309 & 60.86764706 & 13.66666667 & 13.66666667 \\
\hline 11 & DKI Jakarta & 45.33 & 280.67 & 32.53431373 & 42 & 32.53431373 \\
\hline 12 & Jawa Barat & 309.33 & 16.67 & 231.4656862 & 306 & 16.6666667 \\
\hline 13 & Jawa Tengah & 151.33 & 174.67 & 73.46568624 & 148 & 73.46568624 \\
\hline 14 & Di Yogyakarta & 18.33 & 307.67 & 59.53431373 & 15 & 15 \\
\hline 15 & Jawa Timur & 326 & 0 & 248.1323529 & 322.6666667 & 0 \\
\hline 16 & Banten & 60.33 & 265.67 & 17.53431373 & 57 & 17.53431373 \\
\hline 17 & Bali & 14.67 & 311.33 & 63.20098039 & 11.33333334 & 11.33333334 \\
\hline 18 & $\begin{array}{l}\text { Nusa Tenggara } \\
\text { Barat }\end{array}$ & 116.33 & 209.67 & 38.46568624 & 113 & 38.46568624 \\
\hline 19 & $\begin{array}{l}\text { Nusa Tenggara } \\
\text { Timur }\end{array}$ & 60.67 & 265.33 & 17.20098039 & 57.33333334 & 17.20098039 \\
\hline 20 & Kalimantan Barat & 36.33 & 289.67 & 41.53431373 & 33 & 33 \\
\hline
\end{tabular}


Jurnal Sains Komputer \& Informatika (J-SAKTI)

Volume 4 Nomor 1 Maret 2020, pp. 77-87

ISSN: 2548-9771/EISSN: 2549-7200

http://tunasbangsa.ac.id/ejurnal/index.php/jsakti

\begin{tabular}{|l|l|l|l|l|l|l|}
\hline $\mathbf{N o}$ & Nama & Nilai & $\mathbf{C 1}$ & $\mathbf{C 2}$ & $\mathbf{\text { J3 }}$ & $\begin{array}{l}\text { Jarak } \\
\text { terpendek }\end{array}$ \\
\hline $\mathbf{2 1}$ & $\begin{array}{l}\text { Kalimantan } \\
\text { Tengah }\end{array}$ & 40.67 & 285.33 & 37.20098039 & 37.33333334 & 37.20098039 \\
\hline $\mathbf{2 2}$ & $\begin{array}{l}\text { Kalimantan } \\
\text { Selatan }\end{array}$ & 91.67 & 234.33 & 13.79901961 & 88.33333334 & 13.79901961 \\
\hline $\mathbf{2 3}$ & $\begin{array}{l}\text { Kalimantan } \\
\text { Timur }\end{array}$ & 39 & 287 & 38.86764706 & 35.66666667 & 35.66666667 \\
\hline $\mathbf{2 4}$ & Kalimantan Utara & 9 & 317 & 68.86764706 & 5.666666667 & 5.666666667 \\
\hline $\mathbf{2 5}$ & Sulawesi Utara & 23.33 & 302.67 & 54.53431373 & 20 & 20 \\
\hline $\mathbf{2 6}$ & Sulawesi Tengah & 22.67 & 303.33 & 55.20098039 & 19.33333334 & 19.33333334 \\
\hline $\mathbf{2 7}$ & Sulawesi Selatan & 56.67 & 269.33 & 21.20098039 & 53.33333334 & 21.20098039 \\
\hline $\mathbf{2 8}$ & $\begin{array}{l}\text { Sulawesi } \\
\text { Tenggara }\end{array}$ & 15 & 311 & 62.86764706 & 11.66666667 & 11.66666667 \\
\hline $\mathbf{2 9}$ & Gorontalo & 3.33 & 322.67 & 74.53431372 & 0 & 0 \\
\hline $\mathbf{3 0}$ & Sulawesi Barat & 12.33 & 313.67 & 65.53431373 & 8.999999997 & 8.999999997 \\
\hline $\mathbf{3 1}$ & Maluku & 14.5 & 311.5 & 63.36764706 & 11.16666667 & 11.16666667 \\
\hline $\mathbf{3 2}$ & Maluku Utara & 4.67 & 321.33 & 73.20098039 & 1.333333334 & 1.333333334 \\
\hline $\mathbf{3 3}$ & Papua Barat & 9.67 & 316.33 & 68.20098039 & 6.333333334 & 6.333333334 \\
\hline $\mathbf{3 4}$ & Papua & 110 & 216 & 32.13235294 & 106.6666667 & 32.13235294 \\
\hline
\end{tabular}

Tabel 5. Pengelompokan Data Iterasi 1

\begin{tabular}{|l|l|l|l|l|}
\hline \multirow{2}{*}{ No } & \multicolumn{1}{|c|}{ Nama } & \multicolumn{3}{c|}{ Kelompok Data 1 } \\
\cline { 3 - 5 } & & C1 & C2 & C3 \\
\hline 1 & Aceh & & 1 & \\
\hline 2 & Sumatera Utara & & 1 & \\
\hline 3 & Sumatera Barat & & 1 & \\
\hline 4 & Riau & & 1 & \\
\hline 5 & Jambi & 1 & & \\
\hline 6 & Sumatera Selatan & & & 1 \\
\hline 7 & Bengkulu & 1 & & \\
\hline 8 & Lampung & & & 1 \\
\hline 9 & Kep, Bangka Belitung & & & 1 \\
\hline 10 & Kep, Riau & & 1 & \\
\hline 11 & DKI Jakarta & 1 & & \\
\hline 12 & Jawa Barat & & 1 & \\
\hline 13 & Jawa Tengah & & & 1 \\
\hline 14 & Di Yogyakarta & 1 & & \\
\hline 15 & Jawa Timur & & 1 & \\
\hline 16 & Banten & & & 1 \\
\hline 17 & Bali & & 1 & \\
\hline 18 & Nusa Tenggara Barat & & 1 & \\
\hline 19 & Nusa Tenggara Timur & & & 1 \\
\hline 20 & Kalimantan Barat & & 1 & \\
\hline 21 & Kalimantan Tengah & & 1 & \\
\hline 22 & Kalimantan Selatan & & & 1 \\
\hline 23 & Kalimantan Timur & & & 1 \\
\hline 24 & Kalimantan Utara & & & 1 \\
\hline 25 & Sulawesi Utara & & & 1 \\
\hline 26 & Sulawesi Tengah & & & \\
\hline 27 & Sulawesi Selatan & & 1 & 1 \\
\hline 28 & Sulawesi Tenggara & & & 1 \\
\hline 29 & Gorontalo & & & 1 \\
\hline 30 & Sulawesi Barat & & & \\
\hline 31 & Maluku & & & \\
\hline & & & & \\
\hline
\end{tabular}

Analisis Datamining pada Kasus Daerah Pelaku Kejahatan Pencurian (Rinawati)|83 


\begin{tabular}{|l|l|c|c|c|}
\hline \multirow{2}{*}{ No } & \multicolumn{1}{|c|}{ Nama } & \multicolumn{3}{|c|}{ Kelompok Data 1 } \\
\cline { 3 - 5 } & & C1 & C2 & C3 \\
\hline 32 & Maluku Utara & & & 1 \\
\hline 33 & Papua Barat & & & 1 \\
\hline 34 & Papua & & 1 & \\
\hline
\end{tabular}

$$
\begin{aligned}
& \text { C1 : }\{6,8,12,15\} \\
& \text { C2 : }\{1,2,3,4,5,11,13,16,18,19,21,22,27,34\} \\
& \text { C3 : }\{7,9,10,14,17,20,23,24,25,26,28,29,30,31,32,33\}
\end{aligned}
$$

Proses iterasi akan terus berlangsung sampai hasil cluster terakhir sama dengan cluster sebelumnya. Pada penelitian ini cluster berhenti di iterasi 8

\begin{tabular}{|c|c|c|c|c|c|c|}
\hline No & Nama & Nilai & C1 & $\mathrm{C2}$ & C3 & $\begin{array}{l}\text { Jarak } \\
\text { terpendek }\end{array}$ \\
\hline 1 & Aceh & 83.33 & 9.67233333 & 80.28769333 & 71.96403333 & 9.67233333 \\
\hline 2 & Sumatera Utara & 140 & 66.3391 & 136.9544 & 128.6307 & 66.3391 \\
\hline 3 & Sumatera Barat & 61 & 12.6609 & 57.9544 & 49.6307 & 12.6609 \\
\hline 4 & Riau & 109.67 & 36.0057667 & 106.6210667 & 98.2973667 & 36.0057667 \\
\hline 5 & Jambi & 66.33 & 7.32756667 & 63.28773333 & 54.96403333 & 7.32756667 \\
\hline 6 & Sumatera Selatan & 310 & 236.3391 & 306.9544 & 298.6307 & 236.3391 \\
\hline 7 & Bengkulu & 37 & 36.6609 & 33.9544 & 25.6307 & 25.6307 \\
\hline 8 & Lampung & 213.67 & 140.0057667 & 210.6210667 & 202.2973667 & 140.0057667 \\
\hline 9 & $\begin{array}{l}\text { Kep. Bangka } \\
\text { Belitung }\end{array}$ & 18.33 & 55.32756667 & 15.28773333 & 6.96403333 & 6.96403333 \\
\hline 10 & Kep. Riau & 17 & 56.6609 & 13.9544 & 5.6307 & 5.6307 \\
\hline 11 & DKI Jakarta & 45.33 & 28.32756667 & 42.28773333 & 33.96403333 & 28.32756667 \\
\hline 12 & Jawa Barat & 309.33 & 235.6724333 & 306.2877333 & 297.9640333 & 235.6724333 \\
\hline 13 & Jawa Tengah & 151.33 & 77.6724333 & 148.2877333 & 139.9640333 & 77.6724333 \\
\hline 14 & Di Yogyakarta & 18.33 & 55.32756667 & 15.28773333 & 6.96403333 & 6.96403333 \\
\hline 15 & Jawa Timur & 326 & 252.3391 & 322.9544 & 314.6307 & 252.3391 \\
\hline 16 & Banten & 60.33 & 13.32756667 & 57.28773333 & 48.96403333 & 13.32756667 \\
\hline 17 & Bali & 14.67 & 58.99423333 & 11.62106667 & 3.29736667 & 3.29736667 \\
\hline 18 & $\begin{array}{l}\text { Nusa Tenggara } \\
\text { Barat }\end{array}$ & 116.33 & 42.6724333 & 113.2877333 & 104.9640333 & 42.6724333 \\
\hline 19 & $\begin{array}{l}\text { Nusa Tenggara } \\
\text { Timur }\end{array}$ & 60.67 & 12.99423333 & 57.62106667 & 49.29736667 & 12.99423333 \\
\hline 20 & Kalimantan Barat & 36.33 & 37.32756667 & 33.28773333 & 24.96403333 & 24.96403333 \\
\hline 21 & $\begin{array}{l}\text { Kalimantan } \\
\text { Tengah }\end{array}$ & 40.67 & 32.99423333 & 37.62106667 & 29.29736667 & 29.29736667 \\
\hline 22 & $\begin{array}{l}\text { Kalimantan } \\
\text { Selatan }\end{array}$ & 91.67 & 18.00576667 & 88.62106667 & 80.29736667 & 18.00576667 \\
\hline 23 & $\begin{array}{l}\text { Kalimantan } \\
\text { Timur }\end{array}$ & 39 & 34.6609 & 35.9544 & 27.6307 & 27.6307 \\
\hline 24 & Kalimantan Utara & 9 & 64.6609 & 5.9544 & 2.3693 & 2.3693 \\
\hline 25 & Sulawesi Utara & 23.33 & 50.32756667 & 20.28773333 & 11.96403333 & 11.96403333 \\
\hline 26 & Sulawesi Tengah & 22.67 & 50.99423333 & 19.62106667 & 11.29736667 & 11.29736667 \\
\hline 27 & Sulawesi Selatan & 56.67 & 16.99423333 & 53.62106667 & 45.29736667 & 16.99423333 \\
\hline 28 & $\begin{array}{l}\text { Sulawesi } \\
\text { Tenggara }\end{array}$ & 15 & 58.6609 & 11.9544 & 3.6307 & 3.6307 \\
\hline 29 & Gorontalo & 3.33 & 70.32756667 & 0.287733333 & 8.035966667 & 0.287733333 \\
\hline 30 & Sulawesi Barat & 12.33 & 61.32756667 & 9.28773333 & 0.96403333 & 0.96403333 \\
\hline 31 & Maluku & 14.5 & 59.1609 & 11.4544 & 3.1307 & 3.1307 \\
\hline 32 & Maluku Utara & 4.67 & 68.99423333 & 1.621066667 & 6.702633333 & 1.621066667 \\
\hline 33 & Papua Barat & 9.67 & 63.99423333 & 6.621066667 & 1.702633333 & 1.702633333 \\
\hline 34 & Papua & 110 & 36.3391 & 106.9544 & 98.6307 & 36.3391 \\
\hline
\end{tabular}
dengan hasil akhir seperti yang ditunjukkan pada tabel berikut:

Tabel 6. Perhitungan Jarak Pusat Cluster Iterasi 8 
Tabel 7. Pengelompokan Data Iterasi 8

\begin{tabular}{|l|l|l|l|l|}
\hline \multirow{2}{*}{ No } & \multicolumn{2}{|c|}{ Nama } & \multicolumn{3}{c|}{ Kelompok Data 1 } \\
\hline & & \multicolumn{1}{|c|}{ C1 } & \multicolumn{1}{c|}{ C2 } & C3 \\
\hline 1 & Aceh & 1 & & \\
\hline 2 & Sumatera Utara & 1 & & \\
\hline 3 & Sumatera Barat & 1 & & \\
\hline 4 & Riau & 1 & & \\
\hline 5 & Jambi & 1 & & \\
\hline 6 & Sumatera Selatan & & & 1 \\
\hline 7 & Bengkulu & 1 & & \\
\hline 8 & Lampung & & & 1 \\
\hline 9 & Kep. Bangka Belitung & & & 1 \\
\hline 10 & Kep. Riau & 1 & & \\
\hline 11 & DKI Jakarta & 1 & & \\
\hline 12 & Jawa Barat & 1 & & \\
\hline 13 & Jawa Tengah & & & 1 \\
\hline 14 & Di Yogyakarta & 1 & & \\
\hline 15 & Jawa Timur & 1 & & \\
\hline 16 & Banten & & & 1 \\
\hline 17 & Bali & 1 & & \\
\hline 18 & Nusa Tenggara Barat & 1 & & \\
\hline 19 & Nusa Tenggara Timur & & & 1 \\
\hline 20 & Kalimantan Barat & & & 1 \\
\hline 21 & Kalimantan Tengah & & & \\
\hline 22 & Kalimantan Selatan & 1 & & 1 \\
\hline 23 & Kalimantan Timur & & & 1 \\
\hline 24 & Kalimantan Utara & & & 1 \\
\hline 25 & Sulawesi Utara & & & 1 \\
\hline 26 & Sulawesi Tengah & & & 1 \\
\hline 27 & Sulawesi Selatan & 1 & & \\
\hline 28 & Sulawesi Tenggara & & & 1 \\
\hline 29 & Gorontalo & & 1 & \\
\hline 30 & Sulawesi Barat & & & 1 \\
\hline 31 & Maluku & & 1 & \\
\hline 32 & Maluku Utara & & & \\
\hline 33 & Papua Barat & & & \\
\hline 34 & Papua & & \\
\hline & & & & \\
\hline & & & & \\
\hline
\end{tabular}

C1 : $\{1,2,3,4,5,6,8,11,12,13,15,16,18,19,22,27,34\}$

$\mathrm{C} 2:\{29,32\}$

C3 : $\{7,9,10,14,17,20,21,23,24,25,26,28,31,31,33\}$ 


\section{Grafik Persentasi Pengelompokan}

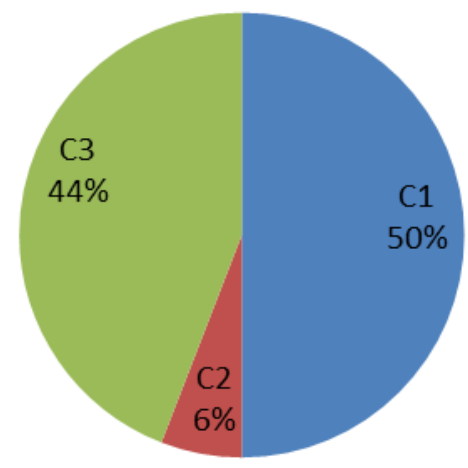

Gambar 2. Grafik Persentasi Pengelompokan Iterasi terakhir

Berdasarkan hal tersebut bahwa teknik $k$-means pada kasus daerah pelaku kejahatan pencurian berdasarkan provinsi dengan menggunakan 3 cluster dengan pengelompokan sebagai berikut:

a) Cluster Tinggi (C1): Aceh, Sumatera Utara, Sumatera Barat, Riau, Jambi, Sumatera Selatan, Lampung, DKI Jakarta, Jawa Barat, Jawa Tengah, Jawa Timur, Banten, Nusa Tenggara Barat, Nusa Tenggara Timur, Kalimantan Selatan, Sulawesi Selatan, Papua,

b) Cluster Normal (C2): Gorontalo, Maluku Utara,

c) Cluster Rendah (C3): Bengkulu, Kep. Riau, Kep. Bangka Belitung, DI Yogyakarta, Bali, Kalimantan Barat, Kalimantan Tengah, Kalimantan Timur, Kalimantan Utara, Sulawasi Utara, Sulawesi Tengah, Sulawesi Tenggara, Sulawesi Barat, Maluku dan Papua Barat.

\section{SIMPULAN}

Berdasarkan hasil penelitian dapat disimpulkan bahwa teknik datamining KMeans dapat diterapkan pada kasus daerah pelaku kejahatan pencurian berdasarkan provinsi yang menghasilkan 3 cluster, yakni cluster tinggi (C1): 17 provinsi, cluster normal (C2): 2 provinsi dan cluster rendah (C3): 15 provinsi. Hasil penelitian dapat menjadi sumber informasi bagi pemerintah khususnya pihak yang berkepentingan bahwa angka kejahatan pencurian yang dikelompokkan berdasarkan provinsi masih sangat tinggi yakni 50\%.

\section{DAFTAR PUSTAKA}

[1] N. Wakhidah, "Clustering Menggunakan K-Means Algorithm ( K-Means Algorithm Clustering )," Fak. Teknol. Inf., vol. 21, no. 1, pp. 70-80, 2014.

[2] M. G. Sadewo, A. P. Windarto, and D. Hartama, "Penerapan Datamining Pada Populasi Daging Ayam Ras Pedaging Di Indonesia Berdasarkan Provinsi Menggunakan K-Means," pp. 60-67, 2016.

[3] Windha Mega Pradnya Dhuhita, "Clustering Menggunakan Metode K-Means untuk Menentukan Status Gizi Balita," J. Inform., vol. 15, no. 2, pp. 160-174, 
2016.

[4] B. M. Metisen and H. L. Sari, "Analisis Clustering Menggunakan Metode KMeans dalam Pengelompokkan Penjualan Produk pada Swalayan Fadhila," J. Media Infotama, vol. 11, no. 2, pp. 110-118, 2015.

[5] L. Teori, "( K-Means Algorithm Implementation For Clustering Of Patients Disease In Kajen Clinic Of Pekalongan) Anindya Khrisna Wardhani Magister Sistem Informasi Universitas Diponegoro," vol. 14, pp. 30-37, 2016.

[6] S. Agustina, D. Yhudo, H. Santoso, N. Marnasusanto, A. Tirtana, and F. Khusnu, "Clustering Kualitas Beras Berdasarkan Ciri Fisik Menggunakan Metode KMeans Algoritma," Clust. K-Means, pp. 1-7, 2012.

[7] N. Hasanah, M. Ugiarto, and N. Puspitasari, "Sistem Pengelompokan Curah Hujan Menggunakan Metode K-Means Di Wilayah Kalimantan Timur," in Prosiding Seminar Nasional Ilmu Komputer dan Teknologi Informasi, 2017, vol. 2, no. 2, pp. 122-126. 